\title{
The Russian Empire and the Soviet Union: too soon to talk of Echoes?
}

\author{
Alexander Morrison
}

Echoes of Empire: Memory, Identity and the Legacy of Imperialism. Edited by: Kalypso Nicolaidis, Berny Sèbe \& Gabrielle Maas (London: I. B. Tauris, 2015) pp.155 - 174

Russia is often considered to be an anomaly amongst the European empires, and its ambivalent status is further clouded by the seventy years of aggressively modernising Soviet rule that preceded its collapse. Across all its former territories, elements of the Soviet and even the Tsarist legacy are still live political issues: tangled borders, new nationalities, patterns of migration, strategic imperatives, and open warfare all function within the ghostly framework of the Russian Empire. This is so even though the destinies of its constituent parts over the last twenty years have been so divergent, ranging from EU membership for the Baltic States to a return to the personality cult in post-communist Turkmenistan. In part this is simply a function of the empire's vastness, and accordingly any assessment, however brief and superficial (as this chapter inevitably will be), must take into a account the long process of Russian expansion, the different circumstances under which territories were incorporated into the empire, and their varied experiences of imperial or Soviet rule. As political circumstances within and outside the former USSR have changed, so, inevitably, have interpretations of Russian imperial history. Immediacy is what makes the Russian case truly distinctive: Russia's relations with the former republics are far from postcolonial, and the Russian federation remains an imperial polity rather than a nation-state. Accordingly, we are not dealing with 'echoes' of imperialism here at all, but with a cacophony of urgent and immediate legacies.

\section{The expansion of Russia}

The course of Russian imperial expansion spanned almost five hundred years, and the process of conquest and incorporation exercises a decisive influence over the imperial legacy today. It is useful, if a little over-simplified, to think of the Russian empire in terms of a series of concentric circles of territory, each of which represents a different phase of expansion, and a process of more or less successful assimilation to the old Muscovite 'core'. Russia herself had been under the suzerainty of the Turco-Mongol Golden Horde until the mid-fifteenth century, and the administrative and psychological legacy of the 'Tatar yoke' to the Russian state remains a matter of considerable debate amongst historians. ${ }^{1}$ The beginnings of Russian Imperialism are usually dated from the fall of Kazan to Ivan the Terrible in 1552, which saw large numbers of Muslim Tatars, together with pagan Turkic and Finno-Ugric groups of the Volga Region, incorporated into what had been a largely Orthodox, Slavic polity. ${ }^{2}$ This was followed by the conquest of two other successor khanates of the Golden Horde, Astrakhan (in the Volga Delta) and Siberia. In the seventeenth century Russia would face a threat from the West, in the form of the Polish-Lithuanian Commonwealth, whilst the Crimean Khanate (under Ottoman suzerainty) on the state's southern flank remained a powerful and largely hostile force. Meanwhile Cossack mercenaries and fur-trappers swiftly spread through Siberia, reaching the Pacific coast at Okhotsk by 1641. The indigenous peoples of Siberia soon found themselves swamped even by the limited number of Russian settlers who flowed into the region in this period, and were often decimated by the diseases and alcoholism 
which they brought in their wake. Russian expansion in the Far East received a check with the treaty of Nerchinsk (1689) which conceded China's control of the Amur valley; nevertheless the empire had acquired a vast tract of territory which gradually attracted peasant settlers, many from the persecuted Old Believer minority. ${ }^{3}$ Stretching from Moscow to the Pacific, all these regions remain part of the Russian federation today, with Russians in an overall majority in all but a few parts of Northern Siberia. However this apparent political and ethnic unity disguises enormous cultural diversity, some of which is formally recognised through the existence of 'autonomous regions' such as Tatarstan, Bashkortostan and Yakutia, whilst some other minorities such as the Muslim Nogais of the Astrakhan region do not appear on maps of Russia at all.

The emergence of the militarised, bureaucratic Petrine state from the late 1600s saw Russia consolidate and expand her position in the West, whilst also penetrating ever more deeply into Asia. Beginning with victory over the Swedes at the battle of Poltava in 1709, over the course of the eighteenth century Russia acquired a vast swathe of European territory stretching from Karelia almost to the Danube, taking in the lands of ancient Rus' in Ukraine, the Baltic and most of Poland along the way. These regions were to present the empire with some of its most intractable problems in the nineteenth century. This was partly because their populations tended to be more prosperous and better-educated than those in Russia proper, whilst their political traditions were at odds with the principle of autocracy: it was in this region that the Tsarist state first had to confront the challenge of romantic nationalism. ${ }^{4}$ With the annexation of what came to be known as the 'Western borderlands' (Zapadnye Okrainy) Russia also acquired its vast, and in official eyes contaminating, Jewish population, and struggled to keep it confined to this 'Pale of Settlement'. On the other hand, the empire found some of its most loyal servants in the Baltic German aristocracy, who played a crucial role within the empire's ruling elite until the Revolution. ${ }^{6}$ The Crimean khanate finally fell in the 1770s, opening up the European steppe north of the Black Sea to peasant colonisation as the Ottoman Empire was rolled back, making this one of Russia's earliest 'oriental' conquests. ${ }^{7}$ This region was renamed 'New Russia' or 'Tauride', the first name reflecting its status as a new colony of settlement, the second its classical heritage as the home of Pontic Greek colonies, and both part of a process which saw a conscious elimination of earlier names which were reminders of the region's Turkic and nomadic past. ${ }^{8}$

Russian expansion in the Caucasus followed a slower and bloodier path. The black-earth and steppe areas between the lower Volga and the Caucasus mountains had begun to attract Russian peasant settlers from the early sixteenth century onwards, but until the late eighteenth century Tsarist power in the region was represented largely by semi-independent communities of Cossacks along the Terek river, whose relationship with the Chechen, Daghestani and Circassian mountaineers of the frontier was far from wholly hostile. ${ }^{9}$ Peter the Great's capture of the Daghestani city of Derbent in 1722 proved short-lived, but in the early 1800s Georgia and Armenia were annexed, whilst Persia lost the northern part of the province of Azerbaijan at the treaty of Gulistan in 1813. The Caucasus Mountains lay athwart Russia's communications with these newly-acquired territories to their South, but the subjugation of the mountaineers would occupy thousands of Russian troops for over fifty years. General Yermolov, in a series of brutal campaigns from 1817-1827, espoused a scorched earth policy which drove an ever-deeper wedge between the Russians and the inhabitants of 
A. Morrison 'The Russian Empire and the Soviet Union: too soon to talk of Echoes?' in Echoes of Empire: Memory, Identity and the Legacy of Imperialism. Edited by: Kalypso Nicolaidis, Berny Sèbe \& Gabrielle Maas (London: I. B. Tauris, 2015) pp.155 - 174

the Northern Caucasus, 'contracting' the middle ground of cultural and economic exchange which had existed before. ${ }^{10}$ His cruelty provoked a general uprising in Chechnya in 1825, which produced the greatest hero of the anti-Russian struggle, Imam Shamil, who was not captured until 1859. The war finally came to an end in 1864, when 300,000 Circassians chose exile in the Ottoman Empire rather than Russian rule. The legacy of the long conflict amongst the Russians was mixed: on the one hand it created a deep and long-lasting distrust of Islam, and brought about a loss of faith in the tactic of absorbing local aristocracies which had served Russia so well in the past, whilst the Muslims of the Caucasus were characterised as 'Savages' and 'Brigands', an attitude that persists to this day. ${ }^{11}$ On the other hand the Caucasus became a vital component of the Russian romantic imagination, inspiring Pushkin, Lermontov and Tolstoy, for whom the mountaineers symbolised a freedom which did not exist in Russian society. ${ }^{12}$ Overall, the European and Caucasian territories Russia acquired in the eighteenth and early nineteenth centuries constitute a more liminal zone, where states that are now independent blur into regions that remain part of the Russian 'metropole'. Whilst those who identify as ethnic Russians are usually a minority in these regions, many Russians would still consider the Caucasus, Ukraine and in particular Crimea to be 'ours' (nash). ${ }^{13}$

Finally we come to the most 'colonial' of Russia's territories in Central Asia, which were generally excluded from the civic structures of Imperial Russia and seen as particularly 'backward' in the Soviet period. With the possible exception of parts of Northern Kazakhstan, few Russians today would consider this region to be truly 'Russian'. The Kazakhs of the Inner Horde came under Russian sovereignty with the submission of Abu'l-Khayr Khan to the Empress Anna in 1732, ${ }^{14}$ and after 1734 the newly-created fortress-town of Orenburg became the centre of Russian influence on the Asian steppe. Despite resistance from part of the Kazakh Middle Horde led by Kenesary Kasimov, ${ }^{15}$ by the late 1850 s a series of campaigns on the Steppe, and the construction of a line of fortresses through Kazakh lands had brought most of this region under Russian control. After a brief check during the Crimean War, the process of conquest continued apace, with the fall of Tashkent in 1865 marking the beginning of Russian incursions into the settled oasis region of Central Asia. Subsequently the Emirate of Bukhara submitted to Russian suzerainty and became a protectorate, whilst Khiva also fell in 1873. 1878 saw the beginning of the exceptionally bloody conquest of Transcaspia, marked by the massacre of thousands of Turkmen by General Mikhail Skobelev at the fortress of Geok-Tepe in $1881 .^{16}$ The empire's southern boundary assumed the form it would retain until 1991 with the annexation of the Kushka oasis in 1885, and of the Pamir region in the 1890s. From the mid 1890s the state encouraged peasant migration from the land-hungry regions of European Russia across the Urals to Siberia and south to the Asiatic steppes, and the numbers of Russian and Ukrainian settlers increased exponentially with the construction of the Transsiberian and Orenburg-Tashkent railways. ${ }^{17}$ By the last years of Tsarist rule there were ambitious plans to swamp the indigenous population of the Steppe and Turkestan with millions more settlers, accompanied by a vast extension of irrigated agriculture. ${ }^{18}$ While the demographic balance in the northern steppe was profoundly altered, there was no question that these territories remained alien - chuzhoi, and populated by inorodtsy - those of a 'different birth'. ${ }^{19}$

Simultaneously the Russian presence in the Far East was consolidated with the annexation of the Amur region and the founding of Vladivostok in the 1850s and 60s, continuing into the early twentieth century with the acquisition of a warm-water naval 
base on the Pacific, Port Arthur, in 1897, the construction of the Chinese Eastern Railway to link Vladivostok and Port Arthur with European Russia via the Transsiberian railway, and the de facto annexation of Manchuria. ${ }^{20}$ Humiliating defeat in the Russo-Japanese war of 1904-5 curbed Russian ambitions in the region, and in the long term would prove of enormous significance to the other European powers, whose colonial subjects elsewhere in Asia were widely encouraged by this defeat of Europeans by Asians. ${ }^{21}$ In this region, then, Russia had been forced to draw in her horns somewhat even before 1917, and today the Primorskii Krai or 'maritime region' around Vladivostok remains, for demographic reasons, one of her more fragile possessions.

\section{Understanding Russian Imperialism}

The question of how to describe and categorise this enormous polity, spanning two continents, at least fifty languages and three major religions, has exercised historians at least since Nikolai Karamzin wrote his Memoir on Ancient \& Modern Russia in the $1820 \mathrm{~s}^{22}$ Russia was a great, land-based empire, with its roots in the early-modern period, whose titular nationality was ill-defined and enjoyed no particular privileges, whose ruling elite was cosmopolitan, with a disproportionate role played by nonRussians, in particular Poles, Baltic Germans and Georgians. It was difficult, if not impossible, to identify a particular territory at the heart of the empire with the Russian 'nation', and at least until the late nineteenth century the core of Russian imperial ideologies was the ruling Romanov dynasty. ${ }^{23}$ With leading noble families such as the Stroganovs and Yusupovs descended from Muslim Tatars, with colonists in Siberia 'going native' rather than the natives becoming Russified, racial boundaries seem blurred. ${ }^{24}$ Class or soslovie (estate), not race, was what determined hierarchies in Russia. Above all, where was that vital distinction between metropole and colony, that barrier between the political, cultural and territorial 'nation' at the heart of Empire, and the colonies at the periphery, so characteristic of 'western' colonialism? Russia's identity is said to be inseparable from Empire, her nationalism warped and weakened by it, her people even described as the chief victims of 'their' empire by some historians. ${ }^{25}$ Even today one cannot really isolate 'Russia' on a map: the rump of the Russian Federation which was left behind after the break-up of the USSR, with its Far Eastern and Siberian territories and its patchwork of 'autonomous' provinces for different nationalities, is very far from being a nation-state. All of this would suggest that if Russia belongs in any 'category', it is that of the early-modern dynastic empires which survived into the modern period, those of the Habsburgs and the Ottomans. Some influential cultural historians have argued that to equate Russian Imperialism with that of the British or French is problematic and inaccurate, but there are also some striking parallels. ${ }^{26}$

In the nineteenth century, views of the nature of Russian Imperialism varied widely both within and outside the empire. While G. N. Curzon could remark that the Russian conquest of Central Asia was 'a conquest of Orientals by Orientals', other observers such as Eugene Schuyler or Francis Skrine viewed Russian Imperialism as simply another (perhaps more backward) manifestation of the wider phenomenon of European expansion. ${ }^{27}$ Within Russia there was an 'Asianist' sub-strand of Slavophile thought among some intellectuals and publicists in Moscow and St Petersburg which

presented the Russians as occupying a unique position between Europe and Asia, giving them a greater affinity with Asiatic peoples and thus (or so it was argued) a 
A. Morrison 'The Russian Empire and the Soviet Union: too soon to talk of Echoes?' in Echoes of Empire: Memory, Identity and the Legacy of Imperialism. Edited by: Kalypso Nicolaidis, Berny Sèbe \& Gabrielle Maas (London: I. B. Tauris, 2015) pp.155 - 174

greater right to rule over them. Slavophile Philosophers such as Nikolai Danilevsky and Konstantin Leontiev argued that Russia had an Imperial Sonderweg, qualitatively different from that of the other European powers and characterised by greater tolerance and assimilation to Russian culture among conquered peoples, ${ }^{28}$ whilst Fyodor Dostoyevsky famously saw Asiatic conquests as a means of escaping Russia's 'backwardness': 'In Europe we were hangers-on and slaves, whereas to Asia we shall go as masters.' 29

However, the officials and army officers who actually administered Russia's (largely Muslim) borderlands in the Caucasus and Central Asia generally saw themselves as Europeans on a civilising mission, frequently finding parallels with the British experience in India or that of the French in Algeria, whilst peasant settlement in the Steppe and Siberia drew forth comparisons with the opening-up of the American West. ${ }^{30}$ Accordingly, by and large, although the diversity and peculiarities of Russian Imperialism were widely acknowledged by Russians and outsiders alike before 1917, it was not considered entirely sui generis, and most Russian commentators were perfectly happy to see Russian expansion across Asia as part of the wider European colonizing and civilizing mission. ${ }^{31}$

It is probable that biological racism was less widespread and influential in the Russian empire than in the West, but it was by no means unknown, and in any case this was only one of many markers of the difference and inferiority of subject peoples, racial, religious and cultural, which the Russians and other Europeans employed. ${ }^{32}$ In the western borderlands, beginning in the early 1860s with draconian restrictions on publications in the 'Little Russian' (Ukrainian) language, the Tsarist state pursued a policy of what is usually known as 'Russification' in an attempt to create a larger 'national' core for the empire, although this policy of repression was never matched by any positive measures to encourage assimilation through schooling, of the kind that took place in France in the same period. ${ }^{33}$ Russia may not have had as clear a distinction between metropole and colony as a 'classic' European maritime empire, but there was an idea of what constituted the 'core' or 'European' areas of the empire, and this was reflected administratively in the distinction between areas under civilian and under military rule, those in which the liberal reforms of the 1860s were applied, and those where they were withheld. ${ }^{34}$ There was no single concept of Russian Imperial 'citizenship', any more than there was in the British empire, and all the evidence of the last years of Tsarism suggests that in Russia's fledgling democratic culture the enjoyment of political rights and 'Europeanness' (if not Russianness) were becoming increasingly closely aligned. ${ }^{35}$

\section{Nation-building in the Soviet Period}

The Russian Revolution of 1917 saw an avowedly anti-Imperial regime inherit (and in many cases reconquer) almost all the non-Russian territories that had been part of the late-Tsarist empire. To many it seemed as if the old empire had simply continued in another guise, and indeed that is how the Soviet Union was presented by many western commentators until its collapse in 1991, with Soviet 'Nationalities policy' seen as nothing more than window-dressing, a cunning disguise for the continuation of colonialism. ${ }^{36}$ However, the reality was more complex than this, both in practice and in representation. With the demise of the Baltic German aristocracy which had made up such an important part of the old Empire's ruling elite, ethnic Russians 
certainly occupied if anything a more dominant place in the structures of Soviet power than they had in the Tsarist state: but this was true mainly at the centre. In the peripheries, where new 'national' republics were formed, non-Russians in the form of locally recruited party cadres wielded far more power than had usually been the case under the Tsarist regime. The early Soviet policy of korenizatsiya, 'striking roots' or nation-building, together with policies promoting mass literacy, industrialisation and anti-religious campaigns were qualitatively different from anything undertaken in the Tsarist period, and are better compared with what was taking place simultaneously in Reza Shah's Iran and Atatürk's Turkey. ${ }^{37}$ In its Asian borderlands the Tsarist state had been content simply to maintain military security and collect taxes, whilst in Poland and Ukraine it had pursued aggressive policies of Russification. In its early years the Soviet state instead strove to overcome the legacy of 'Great Russian Chauvinism' and shepherd its more 'backward' peoples through the national stage which both Lenin and Stalin thought crucial to the development of Socialism. ${ }^{38}$ This was reflected in the historiography of the time, which presented Tsarist Imperialism as cruel, exploitative and negative, and sought to dissociate Soviet rule from it entirely. ${ }^{39}$ To begin with, this was undoubtedly more than just rhetorical windowdressing: even in the traditionally rebellious North Caucasus many Chechens and Daghestanis were active participants in the early Soviet project. ${ }^{40}$ Modern Ukrainian nationalism is arguably in large part a legacy of the korenizatsiya policies of the 1920s and 1930s, which for the first time saw 97\% of Ukrainian schoolchildren making acquaintance with the literary form of their national language. ${ }^{41}$ After the Second World War, the Ukrainian-speaking regions of Poland were incorporated in the Union republic, whose borders also included large numbers of Russian-speakers in the Don region, the formerly nomadic steppes north of the Black Sea with their diverse settler population and cosmopolitan cities (most notably Odessa) and eventually, in 1954, the Crimean Peninsula, purged of its Tatar population during the Second World War and now almost entirely Russian-speaking. However, the vagaries of Soviet boundary-drawing ensured that, whilst Ukraine now had a larger 'national' territory than any Ukrainian nationalist of the nineteenth century would have dreamed of, much of its population had never fully identified as Ukrainian in the first place, a legacy which continues to cause severe problems today.

Elsewhere in the USSR, the late 1930s and the outbreak of the Second World War also saw some significant changes: many elements of korenizatsiya were phased out, at least in the Western regions, although in most cases its nationalist legacy was far too potent to be entirely suppressed. The Russians were officially anointed as the 'elder brothers' of the Soviet family of nations, whilst among historians Tsarist Imperialism was rehabilitated as having had a 'progressive significance' ${ }^{42}$ The postwar years saw increasingly large numbers of Russians being despatched to other Republics, though normally as urban workers or technical experts rather than as agricultural settlers, with the notable exception of Kazakhstan. In the post-Stalin era the autonomy enjoyed by local party structures was not entirely fictional (the 'great cotton scandal' in Uzbekistan in the 1970s was a clear enough instance of local independence, albeit in the form of corruption), ${ }^{43}$ and officially-sanctioned versions of 'national culture' continued to be promoted. The history of inter-ethnic relations in the USSR in large part remains to be written. Whilst there were occasional outbreaks of tension, such as the Pakhtakor football riots in Tashkent in 1969, and the Zheltoqsan protests against the appointment of a Russian general-secretary of the Kazakh communist party in Alma-ata in 1986, in general there seem to have been 
A. Morrison 'The Russian Empire and the Soviet Union: too soon to talk of Echoes?' in Echoes of Empire: Memory, Identity and the Legacy of Imperialism. Edited by: Kalypso Nicolaidis, Berny Sèbe \& Gabrielle Maas (London: I. B. Tauris, 2015) pp.155 - 174

fewer racial tensions than before 1917. Intermarriage between Russians and Muslim peoples (with the exception of the Tatars and Kazakhs) remained relatively rare, ${ }^{44}$ but close social relations were not uncommon: to give just one example, the otherwise illfated 'Virgin Lands' scheme in Northern Kazakhstan gave birth to a strikingly mixed society where Kazakhs, Russian peasant settlers, Caucasian deportees and enthusiastic young Soviet volunteers rubbed shoulders relatively harmoniously. ${ }^{45}$ That this coexisted with widespread racial prejudice among European Slavs towards Jews and Caucasian Muslims in particular is one of the many puzzles of Soviet history, although it seems that racist attitudes towards the minority peoples of the USSR were (and remain) more common among those who lived in European Russia than amongst the Slavs who lived in the cosmopolitan cities of Baku, Tashkent or Almaty, where they mixed with 'Asiatics' on a daily basis. ${ }^{46}$

\section{The fall of Communism and after}

The collapse of the USSR in 1991 saw a scramble by historians and political scientists to explain the demise of the beast they had studied so long, which in many cases led them to come to new conclusions about the nature of Soviet rule. Some espoused the 'deep-freeze' theory - namely that the 'prison of peoples' which was late-Tsarist Russia had remained in suspended animation throughout the seventy years of Soviet rule, before latent nationalist passions were finally unleashed by the crumbling of central authority. ${ }^{47}$ The conflicts which immediately emerged in Tajikistan and the Caucasus were certainly a result of the slackening of central control, although in most cases their roots lay in Soviet-era disputes over borders and access to state patronage rather than in events before 1917. In the absence of mediation from Moscow, war broke out between Azerbaijan and Armenia over the Nagorno-Karabagh enclave, whilst Georgia sought to establish full and direct control over the autonomous provinces of Abkhazia and South Ossetia which fell within its borders, with disastrous results. However, it soon became clear that whilst for the Warsaw pact countries and the Baltic states independence and freedom from Moscow's control could not come soon enough, ${ }^{48}$ the other constituent republics of the USSR were much more ambivalent about leaving it, and thus losing the patronage and arbitration of Moscow. The Central Asian Republics voted in referenda to maintain the USSR, whilst their leaders almost without exception supported the hardline coup of 1991. Furthermore, many of the 'nationalities' in these regions had not even existed before 1917, and could hardly have 're-emerged' in 1991: the 'Uzbeks' were clearly at least in part a creation of the Soviet era. ${ }^{49}$ If anything it was Russian nationalism which destroyed the USSR, as many Russians (not entirely wrongly) saw their Republic as subsidising all the others. The Soviet Union collapsed when Boris Yeltsin succeeded in investing the hollow structures of the Russian Soviet Socialist Republic with real power. ${ }^{50}$

Since then, Russian nationalism has been exploited heavily by the Putin and Medvedev regimes, whilst racism towards migrants from the former Soviet republics of the Caucasus and Central Asia and paranoia regarding Russia's neighbours are increasingly common. ${ }^{51}$ This is reflected in much contemporary Russian historiography, where Russia's Imperial past is regarded with a mixture of nostalgia, self-righteousness and outright jingoism. A figure such as General Mikhail Dmitrievich Skobelev, who ordered the massacre of thousands Turkmen after the siege of Gök-Tepe in 1881 and was excoriated in Soviet historiography, can now be rehabilitated as a 'Hero of Empire'. ${ }^{2}$ Thinly disguised as "Sobolev", the General has 
also figured prominently in two of the best-selling Boris Akunin novels, one of which has been turned into a film whose portrayal of the Ottomans is ripe with old-fashioned 'Orientalism'. 53 A new statue of Skobelev has apparently been planned for Il'in square in Moscow, to replace the original equestrian statue erected on nearby Tverskaya Street in 1912 and destroyed by the Bolsheviks, although it is not clear if it will ever be built. ${ }^{54}$ New statues of General Yermolov, the 'hammer of the Caucasus' have appeared in the North Caucasian towns of Stavropol, Mineral'nye Vody and Pyatigorsk, whilst Orenburg also has a new monument to General V. A. Perovsky, who played a leading role in the conquest of Central Asia. ${ }^{55}$

Since 1991, the former constituent republics of the USSR have become nationstates, but in most cases their 'new' identities rest firmly on Soviet foundations. This is particularly true in Central Asia, whose republics were carved out of the territories of Bukhara, Khiva and Russian Turkestan in the 1920s, in a complex process of negotiation between the Communist leadership in Moscow and local party cadres. This was not, as many Western commentators believed, the product of a deliberate Soviet policy of 'divide and rule' and creation of minorities. Instead it was partly the inevitable product of an attempt to apply ideas of the nation derived from nineteenthcentury Europe to a region where this category made little sense, partly a consequence of relying on the categories used by late-Tsarist ethnographers and census-takers, and partly the result of local horse-trading. ${ }^{56}$ Whilst the new republics had a territorial form (which continued to shift until the 1980s as boundaries were repeatedly tinkered with) their borders were fairly notional: it was the Soviet State which restricted (and ordered) the movement of labour and the patterns of growth and settlement, not the existence of borders. Since independence the hardening of the borders between the five republics has caused numerous problems, particularly in areas where they are closely intermeshed and pay scant attention to geographical features, most notably the Ferghana Valley. ${ }^{57}$ For instance, the region around the city of Khujand (Leninabad in the Soviet era), the northern 'bump' of Tajikistan, is cut off from the rest of the country by a range of mountains, and in the Soviet era was closely integrated both economically and socially with the surrounding regions of Uzbekistan and Kyrgyzstan. After independence Khujand found itself hemmed in on all sides by newly-impermeable borders, with the only outlet a dangerous mountain road to the south. Whilst communications with Dushanbe have now improved, continued bad relations with Uzbekistan ensure that the region remains cut off from its economic hinterland, whilst modern Tajik nationalist ideology, which emphasises both the Persian language and 'Aryan' ethnicity, is particularly alien to this mixed, bilingual semi-enclave. ${ }^{58}$ Meanwhile, at the eastern end of the Ferghana valley, many Uzbek families are now divided by the frontier between Uzbekistan and Kyrgyzstan, something revealed clearly when many of those who fled the 2010 pogroms in Osh found shelter with relatives on the Uzbek side of the frontier. ${ }^{59}$ In each case, these borders were of little or no importance in the Soviet era, and it was only accidentally that they came to define the limits of sovereignty after 1991. Over the coming years they promise to be one of empire's more intractable 'echoes', as there are few signs that they will become more open or relaxed.

With the exception of Kyrgyzstan, and despite the civil war in Tajikistan, the forms of government of the Central Asian republics show considerable (though not complete) continuity with the Soviet period. The personnel are in some cases the same: Islam Karimov in Uzbekistan, Nursultan Nazarbayev in Kazakhstan and, until 
A. Morrison 'The Russian Empire and the Soviet Union: too soon to talk of Echoes?' in Echoes of Empire: Memory, Identity and the Legacy of Imperialism. Edited by: Kalypso Nicolaidis, Berny Sèbe \& Gabrielle Maas (London: I. B. Tauris, 2015) pp.155 - 174

his death, Saparmurat Niyazov in Turkmenistan were all the first secretaries of their republics' respective communist parties before 1991. However, all of these countries, except Turkmenistan, are much more open to outside influences than they were in the Soviet period, and the work of nation and state-building continues much more actively than before, often with brutally repressive results. ${ }^{60}$ This mixture of change and continuity is reflected in historiography. Despite ritualistic denunciations of Russian colonialism in some new historical work, and Karimov's oft-quoted opinion that 'I do not consider the history written in the Soviet era to be history', 61 the national narratives of the new Republics are based largely on those created in the official histories of the Soviet period, complete with spurious theories of ethnogenesis, government-sanctioned 'national heroes', and certain canonical texts in which the culture of the nation is said to reside. The additions normally consist of more monarchical and militaristic characters who were frowned on in the Soviet period (such as Amir Timur in Uzbekistan), and a rehabilitation of the Muslim reformist movements which appeared in the region in the late nineteenth century (denounced as 'bourgeois' in the Soviet period). Nowhere is this truer than in Uzbekistan, where such few historical publications as do emerge follow Karimov's injunction, invariably invoked in the introduction to modern Uzbek historical publications, that 'Historical memory, the restoration of an objective and truthful history of the nation and its territory is given an extremely important place in the revival and growth of national self-consciousness and national pride. ${ }^{62}$ In Uzbekistan history is relentlessly instrumentalised for the purpose of constructing a stronger 'Uzbek' identity: school textbooks portray the Khwarazmshahs, Tamerlane, Babur, Emir Sayyid Muzaffar of Bukhara, the Jadid reformers and the post-1917 Basmachi as an unbroken line of heroic 'Uzbek' nationalists, engaged in a struggle for 'selfdetermination'. ${ }^{63}$ Access to the national archives has become steadily more restricted to those whose output the regime feels it can control, whilst archival documents are selectively employed to create a narrative of national martyrdom in the Tsarist and Soviet periods. ${ }^{64}$ Even academic writing normally echoes older Soviet scholarship on the ethnogenesis of the Uzbek nation, glosses over the complexity of Central Asian society before the national demarcations of 1924, and the degree to which modern Central Asian national identities (particularly 'Uzbek'), far from having been 'suppressed' in the Soviet period, are at least in part a product of early Soviet nationbuilding policies. ${ }^{65}$ The dangers of taking a constructivist approach to the complex history of Uzbek identity were revealed clearly in the furore surrounding the publication of Alisher Ilkhamov's Ethnic Atlas of Uzbekistan in 2002, which was heavily criticised by historians close to the Uzbek Government and subsequently banned. ${ }^{66}$

Russian scholars working in Central Asia have responded with anger and bewilderment to suggestions in recent historiography from the region that the Tsarist or Soviet regimes could be considered 'colonial'. ${ }^{7}$ In the Soviet period, 'colonialism' and 'imperialism' were things only bourgeois powers were capable of: ergo the Soviet Union - and from the 1940s, by a curious process of extension, its Tsarist predecessor - could not be a 'colonial' power. This strand of thinking became entangled with older Slavophile ideas about the 'natural' and 'organic' nature of Russian expansion until for many historians there emerged a firm belief that the Russian people themselves are not capable of being 'colonial' or racist: a belief which co-exists with irrefutable evidence of racism and hate crimes against Caucasians and Central Asians in Russian cities. ${ }^{68}$ 
In the Ukraine, Azerbaijan and Georgia there is now a celebration of the brief periods of 'national independence' enjoyed by these regions between 1917 and ca.1920-21; the Baltic republics meanwhile romanticise the authoritarian regimes which ruled them throughout most of the inter-war period, and have fierce ongoing disputes with Russia over the interpretation and memorialisation of the Second World War, in which Soviet victory over the Nazis saw the re-annexation of Latvia, Lithuania and Estonia to the USSR after $1945 .{ }^{69}$ Resurgent Russian nationalism is perceived as a serious threat in this region, whilst Georgia has already discovered to its cost that despite post-Soviet military decline Russia remains a regional if not a global superpower, and that her leaders claim a special sphere of influence in the territories of the 'near abroad' - the former USSR. ${ }^{70}$

\section{Imperial Legacies}

The Baltic states aside, there are still numerous ties which bind the republics of the former USSR together, and these are more profound, and geographically closer, than those which link the countries of the British Commonwealth, which has its counterpart in the 'Commonwealth of Independent States' (of which, significantly, the Baltic Republics and Georgia are not members). After the collapse of the Soviet Union many Russians left the Central Asian republics (up to a third of the Russian population in Uzbekistan emigrated, mostly to Russia, between 1994 and 2004). ${ }^{71}$ Despite this, many post-Soviet countries still have large Russian minorities (in Kazakhstan they make up over $20 \%$ of the population, in Estonia almost a half), and Russian remains a lingua franca and a path to professional success in all the Central Asian Republics as well as Azerbaijan and Armenia. In Ukraine almost half the population is Russian-speaking. Only in Georgia and the Baltic Republics has there been a concerted effort to shed much of this historic and cultural baggage, and that has caused much conflict. Russia itself still contains numerous 'Autonomous Republics' such as Tatarstan, half of whose population is Muslim, and where there are occasional rumblings which reveal postcolonial tensions. ${ }^{72}$ Most obviously there is Chechnya, where Russia has fought several vicious wars of repression since the mid1990s. The Far-Eastern territories and much of Siberia remain a sparsely-populated settler colony, where Chinese commercial and demographic influence is likely to play a crucial role in years to come. Russia herself is suffering from a rapid decline in population, which combined with steady immigration from the Central Asian republics in particular is likely to alter profoundly the nature of Russian society by the end of this century: some Russian commentators make alarmist predictions that by 2050 ethnic Russians will be in a minority within the Russian Federation. ${ }^{73}$ This is, perhaps, one of the central paradoxes of the former USSR - that migration between its former constituent parts is far greater now than it was in Soviet times, when movement was strictly controlled by permits (something which is paralleled in the postcolonial migrations within the former French and British empires). One of the most profound Soviet legacies is a vast Russophone cultural and institutional sphere which even Central Asian labourers from remote rural backgrounds can navigate with relative ease, at least compared to migration to Western Europe, or even neighbouring regions with which they may have cultural ties such as Iran, Afghanistan and China. Although some Tajiks fled to Afghanistan during the civil war, the migration flows are overwhelmingly from Uzbekistan, Tajikistan and Kyrgyzstan, all of which suffer from high unemployment, into Russia and Kazakhstan, which throughout most of the 
A. Morrison 'The Russian Empire and the Soviet Union: too soon to talk of Echoes?' in Echoes of Empire: Memory, Identity and the Legacy of Imperialism. Edited by: Kalypso Nicolaidis, Berny Sèbe \& Gabrielle Maas (London: I. B. Tauris, 2015) pp.155 - 174

2000s enjoyed an oil-driven construction boom that slowed only temporarily during the financial crisis. ${ }^{74}$ Even though much of the immigration is illegal, the Russian state largely winks at this as it needs cheap labour for its construction sites and to sweep its streets - whilst for the Central Asian Republics remittances from labour migrants represent up to $30 \%$ of GDP, although local governments do little either to facilitate or encourage transfers and investment, and most of the money is spent on traditional forms of immediate consumption, in particular elaborate feasts (tuys) and the building of houses. ${ }^{75}$ As in Germany in the 1960s, the fiction is that these are all Gastarbeiter who will return to their homes once their work is done, but many stay. ${ }^{76}$ Xenophobia and hate crimes are a problem, especially in Moscow, and far-right groups and Russian skinheads often appear to target not just migrants, but all those obviously of non-Russian ethnicity. ${ }^{77}$ Whilst the Putin-Medvedev regime continues at least to pay lip-service to the Soviet ideal of the 'friendship of peoples', it is doing too little to aid integration and acceptance. In some respects this resembles the intolerant reception which migrants from South Asia and the West Indies to Britain and from North Africa to France encountered in the 1950s and 60s - as one journalist puts it: 'Moscow today is France yesterday' ${ }^{78}$ Conversely, across Uzbekistan, Tajikistan and Kyrgyzstan anything up to $50 \%$ of all families (the real proportion is uncertain) have a member working in Russia, and as these are overwhelmingly young men, who are usually married before they leave for work, this leaves hundreds of thousands of husbandless and fatherless families. ${ }^{79}$ Usually they return home for one or two months a year, in winter, but in some cases they start new families in Russia, and do not return. ${ }^{80}$ Thus the post-Soviet period has seen the creation of new social networks of knowledge, labour and kinship that span the territory of the former USSR, and which are denser and more intimate than the formal political ties and economic control which they have replaced.

\section{Conclusion}

The Russian empire before 1917 had many points of resemblance and divergence with the other European Empires. In Central Asia and the Caucasus it looked rather like British India or French Algeria, and these were consciously identified as backward, colonial territories that were never fully assimilated to the Russian 'core', even if the loss of the Caucasus remains highly contested. In Siberia it looked more like Canada or the American West - a successful settler colony which largely obliterated earlier peoples and cultures. In its western borderlands it looked more like the Habsburg or Ottoman Empires, and here Russia, like its multi-ethnic neighbours, was undone by a gradually rising tide of romantic nationalism. Despite the territorial continuity between the Tsarist and Soviet Empires, and the dominant role that continued to be played by Russians, 1917 saw a genuine shift in the nature of Russian imperialism, as the Soviet state sought to transform the lives and identities of its subjects in ways never contemplated under Tsarist rule. Conversely the break-up of the Soviet Union seemed sudden, swift and decisive at the time, and in the case of the Warsaw Pact countries and the Baltic Republics this was perhaps true - although even here the imperial legacy continues to do more than merely echo. Economically, Russia and Kazakhstan in particular have seen staggering changes, though Uzbekistan and Turkmenistan still seem to be stuck in the Brezhnev era. ${ }^{81}$ In the political and cultural sphere, however, the continuities with the USSR are more striking than the changes. This is not simply because even the rump of the USSR which is Russia remains in many ways an imperial formation, or because Russia has recently shown that she is 
still willing and able to be aggressive beyond these borders. It is because the demographic and cultural legacy of the Soviet period is extremely profound: the USSR was much more than a 'prison of peoples', and many of its non-Russian inhabitants did not want to leave it and still regret its demise.

\footnotetext{
${ }^{1}$ See Willard Sunderland, Taming the Wild Field. Colonization and Empire on The Russian Steppe (Ithaca, NY, 2004), 106-7; Sergei Panarin and Dmitri Raevskii ‘Predislovie,' Evraziya. Liudi i Mify (Moscow, 2003), 9-20.

${ }^{2}$ Jaroslaw Pelenski, Russia and Kazan. Conquest and Imperial Ideology, (1438-1560s) (Paris, 1974)

${ }^{3}$ James Forsyth, A History of the Peoples of Siberia (Cambridge, 1992), 28-108; Yuri Slezkine, Arctic Mirrors. Russia and the Small Peoples of the North (Ithaca, NY, 1994), 11-92.

${ }^{4}$ Timothy Snyder, The Reconstruction of Nations. Poland, Ukraine, Lithuania, Belarus 1569-1999 (Newhaven, CN, 2003), 31-50, 117 - 132.

5 John D. Klier, Russia gathers her Jews: The origins of the "Jewish question" in Russia, 1772-1825.
} (DeKalb, IL, 1986); Aleksei Miller and Mikhail Dolbilov, eds., Zapadnye Okrainy Rossiiskoi Imperii (Moscow, 2006)

${ }^{6}$ Dominic Lieven, Russia's Rulers under the Old Regime (Newhaven, CN, 1989), 32-5

${ }^{7}$ Alan W. Fisher, The Russian Annexation of the Crimea 1772-83 (Cambridge, 1970); Brian J. Boeck, 'Containment vs. colonization. Muscovite approaches to settling the steppe' in Peopling the Russian Periphery. Borderland Colonization in Eurasian History, eds. Nicholas Breyfogle, Abby Schrader and Willard Sunderland, (London, 2007), 41-60; Sara Dickinson, 'Russia's first “Orient”. Characterising the Crimea in 1787,' Kritika: Explorations in Russian and Eurasian History, 3,1 (2002), 3-25

${ }^{8}$ Sunderland, Taming the Wild Field, 69-70.

${ }^{9}$ Thomas M. Barrett, At The Edge Of Empire: The Terek Cossacks And The North Caucasus Frontier, 1700-1860 (Boulder, CO, 1999)

${ }^{10}$ John Baddeley, The Russian Conquest of the Caucasus (London, 1908), 130; Thomas Barrett, 'Lines of Uncertainty. The Frontiers of the Northern Caucasus' in Imperial Russia: New Histories for the Empire, eds., Jane Burbank and David Ransel, (Bloomington, IN, 1998), 157-8, 166; Moshe Gammer, Muslim Resistance to the Tsar (London, 1994)

${ }^{11}$ Vladimir Bobrovnikov, Musul'mane Severnogo Kavkaza. Obuchai, Pravo, Nasilie (Moscow, 2002), 169

${ }^{12}$ Susan Layton, Russian Literature and Empire. The Conquest of the Caucasus from Pushkin to Tolstoy (Cambridge, 1994); Susan Layton, 'Nineteenth-Century Russian mythologies of Caucasian Savagery' in Russia's Orient: Imperial Borderlands and Peoples 1700 - 1917, eds., Daniel Brower and Edward Lazzerini (Bloomington, IN, 1997), 80-99; Austin Jersild, Orientalism and Empire (Montreal, 2002)

${ }^{13}$ This modern sense of possessiveness over the Caucasus is explored rather unsatisfactorily in Bruce Grant, The Captive and the Gift: Cultural Histories of Sovereignty in Russia and the Caucasus (Ithaca, NY, 2009)

${ }^{14}$ Michael Khodarkovsky, Russia's Steppe Frontier. The Making of a Colonial Empire 1500-1800 (Bloomington, IN, 2002), 152-60; I. V. Erofeeva, Istoriya Kazakhstana v Russkikh Istochnikakh XVIXX vekov Vol.III Zhurnaly i Sluzhebnye Zapiski Diplomata A. I. Tevkeleva po Istorii i Etnografii Kazakhstana. (Almaty, 2005), 51-64

${ }^{15}$ Erumkhan Bekmakhanov, Kazakhstan v 20-40 gody XIX veka (Alma-Ata, 1947); Stephen Sabol 'Kazak Resistance to Russian Colonization. Interpreting the Kenesary Kasymov Revolt 1837 - 1847' Central Asian Survey 22,2-3 (2003), 231-252.

${ }^{16}$ Lt-Gen M. A. Terentiev, Istoriya Zavoevaniya Srednei Azii (St Petersburg, 1906) 3 Vols; David Mackenzie The Lion of Tashkent. The Career of General M. G. Cherniaev (Athens, GA, 1974); Alexander Morrison, Russian Rule in Samarkand 1868-1910. A comparison with British India (Oxford, 2008), 11-24

${ }^{17}$ Gulnar Kendirbai, Land and People: the Russian Colonization of the Kazakh Steppe (Berlin, 2002)

${ }^{18}$ A. P. Krivoshein, Zapiska Glavnoupravlyaushago Zemleustroistvom i Zemledeliem o poezdke $v$ Turkestanskii krai v 1912 godu (St Petersburg, 1912).

${ }^{19}$ Alexander Morrison " "Sowing the seed of National Strife in this Alien Region". The Pahlen Report and Pereselenie in Turkestan' Acta Slavica Iaponica 31 (2012), 1-29. 
A. Morrison 'The Russian Empire and the Soviet Union: too soon to talk of Echoes?' in Echoes of Empire: Memory, Identity and the Legacy of Imperialism. Edited by: Kalypso Nicolaidis, Berny Sèbe \& Gabrielle Maas (London: I. B. Tauris, 2015) pp.155 - 174

${ }^{20}$ David Wolff, To the Harbin Station. The Liberal Alternative in Russian Manchuria 1898-1914 (Stanford, CA, 1999); David Schimmelpenninck van der Oye, Towards the Rising Sun. Russian Ideologies of Empire and the path to war with Japan (DeKalb, IL, 2001)

${ }^{21}$ Something grimly predicted by General Alexei Kuropatkin, the War Minister and commander who was widely blamed in Russia for the misconduct of the war. A. N. Kuropatkin The Russian Army and the Japanese War, (London, 1908), II, 195-6

${ }^{22}$ Richard Pipes (ed. \& trans.) Karamzin's Memoir on Ancient \& Modern Russia (Ann Arbor, MI, 2005)

${ }^{23}$ On the symbolic 'performance of power' associated with court rituals and imperial journeys see Richard Wortman, Scenarios of Power. Myth and Ceremony in the Russian Monarchy (Princeton, NJ, 1995, 2000), 2 Vols.

${ }^{24}$ Willard Sunderland, 'Russians into Iakuts? "Going Native” and Problems of Russian National Identity in the Siberian North, 1870s-1914' Slavic Review, 55,4 (1996), 806-825.

${ }^{25}$ Austin Jersild, "'Russia," from the Vistula to the Terek to the Amur,' Kritika, 1,3 (2000), 531-46;

${ }^{26}$ Geoffrey Hosking, Russia, People and Empire (London, 1996) 39-40; Orlando Figes, Natasha's Dance. A Cultural History of Russia (Harmondsworth, 2002), 381-2.

${ }^{27}$ G. N. Curzon, Russia in Central Asia (London, 1889), p. 392; Eugene Schuyler, Turkistan. Notes Of A Journey In Russian Turkistan, Khokand, Bukhara, and Kuldja (London, 1876), 2 Vols; Francis Skrine and E. Denison Ross, The Heart of Asia (London, 1899), 408-416.

${ }^{28}$ See Nikolay Danilevsky, Rossiya i Evropa (1871) (Moscow, 2003); K. Leont'ev 'Kakoe sochetanie obstoyatel'stv nam vygodnee vsego?' Grazhdanin No.91 (1882) reprinted in Vostok, Rossiya $i$ Slavyanstvo (Moscow, 1996), 70.

${ }^{29}$ Fyodor Dostoevsky, 'Dnevnik Pisatelya III Geok-Tepe - Chto takoe dlya nas Aziya?' Polnoe Sobranie Sochinenii, (St Petersburg, 1896), Vol.XXI, 513-23.

${ }^{30}$ Alexander Morrison, 'Russian Rule in Turkestan and the example of British India,' Slavonic \& East European Review, 84,4 (2006), 666-707; W. Bruce Lincoln, The Conquest of a Continent. Siberia and the Russians (London, 1993), 263-9.

${ }^{31}$ P. P. Semenov, 'Znachenie Rossii v kolonizatsionnom dvizhenii evropeiskikh narodov' Izvestiya Imperatorskogo Russkago Geograficheskago Obshchestva, Vol. XXVIII, (1892), 358-9.

${ }^{32}$ N. A. Riasanovsky, 'Asia through Russian Eyes' in Russia and Asia, ed., W. S. Vucinich (Stanford, CA, 1972), 3-29; Eugene M. Avrutin, 'Racial Categories and the Politics of (Jewish) Difference in Late Imperial Russia’ Kritika, 8,1 (2007), 13-40; Marina Mogil'ner, Homo Imperii. Istoriya fizicheskoi antropologii v Rossii (Moscow, 2008).

${ }^{33}$ Alexei Miller, The Ukrainian Question (Budapest, 2003), 247-60; Eugene Weber, Peasants into Frenchmen. The Modernization of Rural France, 1870-1914 (Stanford, CA, 1976); 'Russification' is used to translate two separate terms from Russian: 'rusifikatsiya' and 'obrusenie'. The latter is generally held to have a less politicised meaning, implying voluntary and gradual cultural assimilation. ${ }^{34}$ Kimitaka Matsuzato, 'General-Gubernatorstva v Rossiiskoi Imperii' Novaya Imperskaya Istoriya Postsovetskogo Prostranstva (Kazan’ 2004), 456-8; Olga Maiorova From the Shadow of Empire Defining the Russian Nation through Cultural Mythology, 1855 - 1870 (Madison, WI, 2010), 5-15.

35 Alexander Morrison, 'Metropole, Colony, and Imperial Citizenship in the Russian Empire' Kritika, 13,2 (2012), $327-364$.

${ }^{36}$ H. Seton-Watson, 'Soviet Nationality Policy' Russian Review 15,1 (1956), 3-13; Richard Pipes, The Formation of the Soviet Union. Communism and Nationalism 1917-1923 (Cambridge, MA, 1970)

${ }^{37}$ Adeeb Khalid, 'Backwardness and the Quest for Civilization: Early Soviet Central Asia in Comparative Perspective,' Slavic Review, 65, 2 (2006) 231-251; Adeeb Khalid, 'The Soviet Union as an Imperial Formation: A View from Central Asia' in Ann Stoler, Carole McGranahan, and Peter Perdue (eds.), Imperial Formations, (Santa Fe, 2007), 123-151.

${ }^{38}$ The literature on this period is now enormous. See in particular Ingeborg Baldauf, 'Some thoughts on the making of the Uzbek Nation,' Cahiers du Monde Russe et Soviétique, 32,1 (1991), 79-96; Yuri Slezkine, 'The USSR as a Communal Apartment, or how a Socialist State promoted Ethnic Particularism' Slavic Review 53,2 (Summer 1994), 414-452; Terry Martin, The Affirmative Action Empire (Ithaca, NY, 2000); Adrienne Edgar, Tribal Nation. The making of Soviet Turkmenistan (Princeton, NJ, 2004); Adeeb Khalid, 'The Soviet Assault on Islam,' Islam after Communism. Religion and Politics in Central Asia (Berkeley, CA, 2007), 50-83.

${ }^{39}$ M. N. Pokrovskii, Diplomatiya i Voiny Tsarskoi Rossii v XIX Stoletii (Moscow, 1923); G. Safarov, Kolonial'naya Revolyutsiya (Moscow, 1921); P. G. Galuzo, Turkestan-Koloniya (Moscow, 1929).

${ }^{40}$ Alex Marshall The Caucasus under Soviet Rule (London, 2010), 161-207.

${ }^{41}$ Orest Subtelny Ukraine. A History (Toronto, 1990) 324, 524-536. 
${ }^{42}$ For an as yet unsurpassed account of the contortions of Soviet historiography see Lowell Tillett, The Great Friendship. Soviet Historians on the Non-Russian Nationalities (Chapel Hill NC, 1969); See also Eli Weinermann, 'The Polemics between Moscow and Central Asians on the Decline of Central Asia and Tsarist Russia's Role in the History of the Region' Slavonic \& East European Review, 71,3 (1993), 428-81.

${ }^{43}$ Olivier Roy The New Central Asia. Geopolitics and the Birth of Nations (London, 2000), 109-112, 125.

${ }^{44}$ Racial intermarriage is the subject of an ongoing study by Adrienne Edgar, some preliminary results of which can be found in Adrienne Edgar 'Rulers and Victims reconsidered. Geoffrey Hosking,

"Russians of the Soviet Union," Kritika, 13,2 (2012), 429-40.

${ }^{45}$ Michaela Pohl, "The 'planet of one hundred languages' Ethnic relations and Soviet identity in the Virgin Lands" in Nicholas Bregfoyle, Abby Schrader and Willard Sunderland (eds.) Peopling the Russian Periphery (London, 2007), 238-261.

${ }^{46}$ There is as yet little work on Soviet cosmopolitanism, but for a thought-provoking, if rather diffuse, anthropological study, see Bruce Grant, 'Cosmopolitan Baku,' Ethnos 75,2 (2010), 123-147.

${ }^{47}$ See for instance Geoffrey Hosking, 'The Flawed Melting-Pot,' The Awakening of the Soviet Union (Cambridge, MA, 1991), 92-116.

${ }^{48}$ Snyder Reconstruction of Nations $232-255$.

${ }^{49}$ The first Western historian to fully recognise and explore this was Ronald Suny in The Revenge of the Past: Nationalism, Revolution, and the Collapse of the Soviet Union (Stanford, CA, 1993).

${ }^{50}$ John Morrison, Boris Yeltsin. From Bolshevik to Democrat (New York, 1991) 161-2, 259-69, 28892; Roy, The New Central Asia, 125-9.

${ }^{51}$ For a fine satire on this tendency see Shamil Idiatullin and Evgenii Belov, 'Rossiya v kol'tse zla' Kommersant-Vlast' 23/10/2006 (http://www.kommersant.ru/articles/2006/neighbors.html accessed 05/09/2011)

${ }^{52}$ B. Kostin, Zhizn zamechatel'nykh lyudei-Skobelev (Moscow, 2000); Evgenii Glushchenko, Geroi Imperii (Moscow, 2001) (this jingoistic volume also contains uncritical biographies of K.P. von Kaufman and M.G. Cherniaev); V. I. Gusarov, General M. D. Skobelev. Legendarnaya slava $i$ nesbyvshiesya nadezhdy (Moscow, 2003)

${ }^{53}$ Boris Akunin, Turetskii Gambit \& Smert' Akhillesa (Moscow, 1998) translated as Turkish Gambit and The Death of Achilles (San Diego, CA, 2005-6)

54 'Pamyatnik generalu Skobelevu poyavit'sya v Il'inskom skvere v Moskve' regnum.ru 19/12/2005 (www.regnum.ru/news/562302.html accessed 05/09/2011)

${ }^{55}$ Sergei Rudkovskii 'Pamyatnik Generalu Ermolovu otkryli v Pyatigorske' Rianovosti 11/09/2010 http://ria.ru/society/20100911/274705127.html; I saw the monument to Perovsky when in Orenburg in July 2011.

${ }^{56}$ There is now an extensive literature on this - see Arne Haugen, The Establishment of National Republics in Soviet Central Asia (Basingstoke, 2003); Paul Bergne, The Birth of Tajikistan. National Identity and the Origins of the Republic (London, 2007)

${ }^{57}$ See Madeleine Reeves, 'Locating danger: konfliktologiia and the search for fixity in the Ferghana Valley borderlands.' Central Asian Survey, 24,1 (2005), 67-81 \& Idem 'Travels in the margins of the state: everyday geography in the Ferghana Valley borderlands' in Jeff Sahadeo and Russell Zanca (eds), Everyday Life in Central Asia Past and Present (Bloomington, IN, 2007) 281-300.

${ }^{58}$ Olivier Ferrando, 'Soviet population transfers and interethnic relations in Tajikistan: assessing the concept of ethnicity' Central Asian Survey, 30,1 (2011), 39-52

${ }_{59}$ Madeleine Reeves, 'A Weekend in Osh' London Review of Books, 32, 13 (8th July 2010) 17-18 http://www.lrb.co.uk/v32/n13/madeleine-reeves/a-weekend-in-osh (accessed 04/09/2011)

${ }^{60}$ See Khalid, Islam after Communism, 168-203.

${ }^{61}$ See for instance D. A. Alimova (ed.) Tragediya Sredneaziatskogo Kishlaka (Tashkent, 2006) I, 4

${ }^{62}$ Islam Karimov, Uzbekistan on the Threshold of the Twenty-First Century (London, 1997) p.86.

${ }^{63}$ Jumaboi Rahimov, Istoriya Uzbekistana Vtoraya polovina XIX veka - nachalo XX veka Klass 9 (Tashkent, 2001), 5; This book was withdrawn from circulation in 2003 at the request of the Russian ambassador, but its replacement by G. A. Khidoyatov, whilst containing fewer anti-Russian sentiments, is otherwise not much of an improvement.

${ }^{64}$ Jeff Sahadeo, "'Without the Past there is No Future" Archives, History, and Authority in Uzbekistan' Antoinette Burton (ed.) Archive Stories. Facts, Fictions, and the Writing of History (Durham, NC, 2005), 45-67.

${ }^{65}$ Marlène Laruelle, 'The Concept of Ethnogenesis in Central Asia: Political Context and Institutional Mediators (1940-50)’ Kritika, 9,1 (2008), 169-188. 
A. Morrison 'The Russian Empire and the Soviet Union: too soon to talk of Echoes?' in Echoes of Empire: Memory, Identity and the Legacy of Imperialism. Edited by: Kalypso Nicolaidis, Berny Sèbe \& Gabrielle Maas (London: I. B. Tauris, 2015) pp.155 - 174

${ }^{66}$ Alisher Il'khamov, Etnicheskii Atlas Uzbekistana (Tashkent, 2002); See D. A. Alimova, 'Neoproverzhimo dokazana antinauchnost' gipotezy o tom, chto uzbekskaya natsiya poyavilas' v XVI veke' Interview with UzA. $15^{\text {th }}$ August 2005 http://www.centrasia.ru/newsA.php4?st=1124137320 (accessed 05/09/2011) in which the then head of the Historical Institute of the Uzbek Academy of Sciences condemns the 'unscientific' nature of Il'khamov's argument that the Uzbeks first appear in recorded history in the sixteenth century (which they did). See further the forum on 'Constructing a national history in the language of Soviet Science after the Collapse of the USSR: the Case of Uzbekistan' Ab Imperio 2005/4, 279 - 360, A. Ilkhamov 'Archaeology of Uzbek Identity' \& Adeeb Khalid 'The Modernity of Identity, On A . Ilkhamov's “Archaeology of Uzbek Identity” in Anthropology and Archaeology of Eurasia, 44,4 (2006), 10-36, 86-91.

${ }^{67}$ On this see in particular the essays by S. V. Timchenko \& V. Germanova on, respectively, modern Kazakh and modern Uzbek historiography, which make up appendices $1 \& 2$ of S. Abashin, D. Arapov and N. Bekmakhanova (eds.) Tsentral'naya Aziya v sostave Rossiiskoi Imperii (Moscow, 2007), 338381.

${ }^{68}$ Andreas Umland, 'Das Problem der "Unterforschung" des postsowjetischen russischen Ultranationalismus' Russland-Analysen, 218 (2011), 16-17.

${ }^{69}$ This came to a head in Spring 2007 when the Estonian Government dismantled a Soviet-era War Memorial; see Luke Harding 'Protest by Kremlin as Police quell riots in Estonia' The Observer Sunday $29^{\text {th }}$ April 2007.

${ }^{70}$ Simon Tisdall, 'The Bear is Back' The Guardian Thursday $31^{\text {st }}$ July 2008; 'Russia. A New Confrontation?' House of Commons Defence Committee Report, together with formal minutes, oral and written evidence (London, 2009)

http://www.publications.parliament.uk/pa/cm200809/cmselect/cmdfence/276/276.pdf (accessed 07/10/2009)

71 'Grustnaya statistika: za poslednee desyatiletie iz Uzbekistana uekhal kazhdyi tretii Russkii' fergana.ru 06/09/2004 (http://www.fergananews.com/article.php?id=3145 accessed 05/09/2011)

${ }_{72}$ Most recently a scandal surrounding the Tatar newscaster and head of the Tatarstan state television company El'mira Israfilova, who openly referred to the Russian population of the region as 'occupiers': 'V Tatarstane otkazalis' vozbuzhdat' delo v otnoshenii tatarskoi zhurnalistki, nazvavshei russkikh “okkupantami” regnum.ru 10/08/2011 (http://www.regnum.ru/news/polit/1434156.html accessed 05/09/2011)

${ }^{73}$ Andrei Vaganov, 'Migranty berut revansh. Bogateiiushchaya Rossiya ne mozhet ostanovit' sokrashchenie chislennosti sobstvennogo naseleniya' Nezavisimaya Gazeta 25/10/2006 (http://www.ng.ru/politics/2006-10-25/1_migranty.html accessed 05/09/2011)

${ }^{74}$ Guzal' Mirzarakhimova 'Kazakhstan: gastarbeiterov men'she ne stanet' fergana.ru 09/10/2009 (http://www.fergananews.com/article.php?id=6327\&print=1 accessed 05/09/2011)

${ }^{75}$ Madeleine Reeves, 'Black Work, Green Money: Remittances, Ritual, and Domestic Economies in Southern Kyrgyzstan' Slavic Review 71,1 (2012), 108-134; See further Erica Marat, 'Labour Migration in Central Asia: implications of the global economic crisis' Silk Road Paper (May 2009) (http://www.silkroadstudies.org/new/docs/silkroadpapers/0905migration.pdf accessed 05/09/2011) for a useful overview of the migration phenomenon in English. More detailed statistics and descriptions of migrant motivations for Uzbekistan can be found in E. V. Abdullaev, Trudovaya Migratisya $v$ Respublike Uzbekistan. Sotsial'nye, pravovye i gendernye aspekty (Tashkent, 2008).

${ }^{76}$ V. I. Mukomel and I. M. Kuznetsov (ed.), Adaptatsionnye vozmozhnosti i setevye svyazi migratsionnykh etnicheskikh men'shinstv (Moscow, 2005).

${ }^{77}$ Galina Sapozhnikova, 'Hate crimes in Russia: Citizens of former Soviet republics fear Russia's streets’ Komsomolskaya Pravda 28/04/2008 (http://www.kp.ru/daily/24088.5/320878/ accessed 18/05/2012).

${ }^{78}$ Mikhail Kalishevskii, 'Rossiya: Kak byt i zhit' s “ponaekhavshimi”?' fergana.ru 01/10/2010 (http://www.fergananews.com/article.php?id=6747 accessed 05/09/2011). This article includes some remarkable photographs of the prayers for the feast of Qurban Bairam in Moscow.

${ }^{79}$ A 2006 Tajik documentary film - Georgii Dzalaev \& Alovuddin Abdulloev's 'Novaya Penelopa' ('The New Penelope') - chronicles the lives of wives and children left behind in Tajikistan.

${ }^{80}$ See Mansur Mirovaliev, 'Odissieya uzbekskikh gastarbeiterov v avtobuse - prizrake' fergana.ru 30/08/2009 (http://www.fergananews.com/article.php?id=6282 accessed 05/09/2011) for an account of the lengthy bus-journey made by migrants from Uzbekistan to Moscow each year.

${ }^{81}$ On the divergent economic trajectories of Kazakhstan and the other Central Asian republics since 1991 see Richard Pomfret, The Central Asian Economies since Independence (Princeton, NJ, 2006) 122. 